\title{
PRECIOUS Professional Resources in Early Childhood Intervention: Online tools and standards
}

\begin{abstract}
Within the European Lifelong learning Project PRECIOUS (www.precious.at) a Master curriculum towards the training of professionals in Early Childhood was developed. Precious is based on increased empirical data, that a) ECI requires an academic professional training and $b$ ) that specific professional trainings are correlated with better effects. This 2-year training $\left(120\right.$ ECTS) within the $1^{\text {st }}$ year deepens the scientific aspect of ECI (Scientific Research in ECI: 15 ECTS; Recognition and Detection: 10 ECTS; Working together with Families: 10 ECTS; Working in Teams: 10 ETCS; Individual Intervention: 10 ECTS, Personal Competences: 5 ECTS). Within the $2^{\text {nd }}$ year 3 possible "specialised strands" are available, focussing on diverse needs of professionals:Specialisation A: "Management, Research and Quality Control in ECI" (60 ECTS, Specialisation B: "Resilient Families" focusing on the needs of socially disadvantaged families, and Specialisation C: "Inclusive support" focusing on specific syndromes (autism, complex learning difficulties, low birth weight babies). The Master Courses will be implemented in Germany (Gera, Nordhausen, Hamburg) and - in future - will enable international European courses, supported by specifically developed elearning-tools and online-resources.
\end{abstract}

Key words: Early intervention, professional training, online resources.

\section{Background of the Project}

The Lifelong Learning Project PRECIOUS (www.precious.at) was based on previous efforts within different European partner countries to increase the quality of training for professionals in the field of early childhood intervention.

As the different training systems within the European Union can be assessed as diverse and to a large extent depend on historical developments within the countries themselves, it was the

\footnotetext{
${ }^{1}$ Ph.D., SINN, Graz Austria; Medical School Hamburg, Germany, (E-mail: office@ sinn-evaluation.at)
} 
goal of the previous EBIFF project (www.ebiff.org) to enable assessment and matching processes between personal and institutional curricula and develop a European framework.

Even though only some empirical data is available relating to the correlation of qualification levels of professionals and quality of the service delivered (Bailey et al., 1991; Granlund \& Akesson, 1996; Pretis, 1998, McMullen \& Alat, 2002, Maude et al., 2010) it can be hypothesised that a specific (professional) training in the field of early childhood intervention should show a higher impact on child and family outcomes.

There is a consensus within the international scientific community that the activities carried out in the field of early childhood intervention should be based on a profound professional training (Peterander, 1996; Eurlyaid, 1997; Pretis, 2006, Applequist et al. 2010), as professionals face diverse challenges in work with families, children and transdiciplinary teams. Speck (1996) highlights that ECI can be assessed as the most complex bio-psychosocial intervention, as it addresses - the child, the family in its social network-contacts and involved professionals.

After the implementation of ECI systems within the last decade in most of EU27, issues of efficiency, quality and training have become more and more relevant during the last few years. The report of the European Agency (European Agency, 2005) also highlights the importance of professional qualifications, and respect for national and cultural diversity. In addition the discussion about efficiency and efficacy directly relates to the importance of professional qualifications: higher qualified staff are likely to perform more efficiently, and increase the prevention effect (and therefore reduce the cost factor).

On the other hand the discussion about qualification was also nurtured by the needs of the professionals themselves in their daily work in terms of:

a. communication skills and skills in listening to the family and working in teams (Carpenter \& Herbert, 1994; Carpenter, 1997),

b. assessing the needs of the family in terms of management skills within ECI centres and structures and

c. new methodological needs regarding new target groups (e.g. parents from a socially disadvantaged background or mentally vulnerable parents as addressed in the LLL project www.strong-kids.eu).

Generally it can be observed that most European countries have an observable tendency towards standards, both in training and service in the field of early childhood intervention (http://www.european-agency.org/agency-projects/early-childhood-intervention).

\section{The process and results within the PRECIOUS group}

\section{European Masters Curriculum Early Childhood Intervention}

The international PRECIOUS group consisted of 12 partners from 9 different countries which, within several work meetings, created a modular training framework for early childhood intervention. This training framework represents a 120 ECTS masters degree, separated into two stages:

a. "basic" methodological input ( $1^{\text {st }}$ year, 60 ECTS) focusing on research, detection and diagnosis, family cooperation, team work and evidence-based individual intervention methods and

b. "specialisation" $\left(2^{\text {nd }}\right.$ year, 60 ECTS $)$ with three strands: 
i) Focusing on "management and organisation skills" in early childhood intervention

ii) "Fostering resilience" in new target groups of early childhood intervention

iii) Increasing competencies in the field of "established disabilities"

These three specialisations represent to a large extent training needs based on previous research. Table 1 shows the overall curriculum

Table 1. Overall Curriculum

\begin{tabular}{|c|c|c|c|c|c|}
\hline \multicolumn{6}{|c|}{$\begin{array}{c}\text { Masters Studies } \\
\text { European Masters Early Childhood Intervention } \\
\text { Full Time Studies }\end{array}$} \\
\hline \multicolumn{2}{|l|}{ BASIC } & & & & \\
\hline Field of Competences & $\begin{array}{l}\text { Module } \\
\text { No. }\end{array}$ & $\begin{array}{l}\text { Modules/ } \\
\text { Courses }\end{array}$ & $\mathbf{C P}$ & \multicolumn{2}{|c|}{$\begin{array}{c}\text { Exam } \\
\text { performance }\end{array}$} \\
\hline \multirow{3}{*}{ 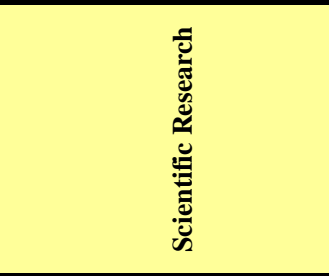 } & M 1.1 & $\begin{array}{l}\text { Scientific research in the field of early childhood } \\
\text { intervention }\end{array}$ & 10 & 2 & $\begin{array}{l}\text { EXA } \\
\text { PRA }\end{array}$ \\
\hline & M 1.2 & Autonomy and Resource Orientation & 5 & 1 & EXA \\
\hline & \multicolumn{2}{|l|}{ Sum } & 15 & & \\
\hline \multirow{3}{*}{ 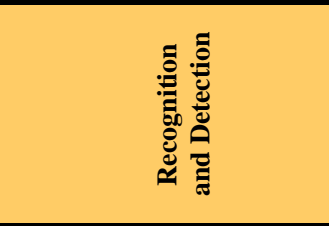 } & M 2.1 & Models of recognition & 5 & 1 & $\begin{array}{l}\text { EXA } \\
\text { PRA }\end{array}$ \\
\hline & M 2.2 & Early Childhood Intervention as Network Cooperation & 5 & 1 & ESY \\
\hline & \multicolumn{2}{|l|}{ Sum } & 10 & & \\
\hline \multirow{4}{*}{ 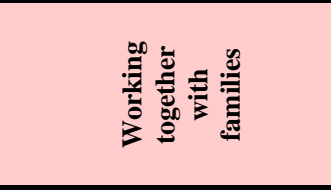 } & M 3.1 & The family as a system & 2 & 1 & OEX \\
\hline & M 3.2 & Recognising and responding to the needs of the family & 4 & 1 & ESY \\
\hline & M 3.3 & Ways of intervention with and within the family & 4 & 1 & WRF \\
\hline & \multicolumn{2}{|r|}{ 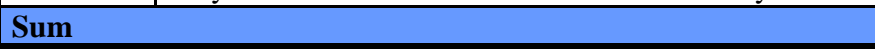 } & 10 & & \\
\hline \multirow{2}{*}{ 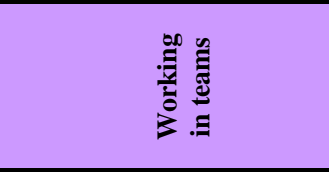 } & M 4 & Working in teams & 10 & 2 & ORF \\
\hline & \multicolumn{2}{|l|}{ Sum } & 10 & & \\
\hline \multirow{6}{*}{ 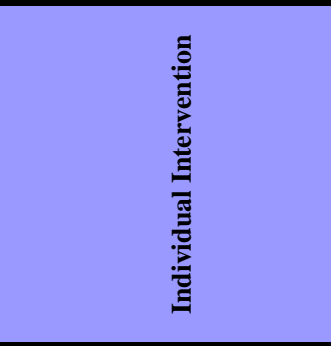 } & M 5.1 & Diversity of Support Needs & 2 & 1 & EXA \\
\hline & M 5.2 & $\begin{array}{l}\text { The Role of the Individual Family Support Plan as } \\
\text { Instrument of Diagnosis }\end{array}$ & 2 & 1 & $\begin{array}{l}\text { EXA } \\
\text { PRA }\end{array}$ \\
\hline & M 5.3 & Hypothesis Based Support Together with the Family & 2 & 1 & PRA \\
\hline & M 5.4 & $\begin{array}{l}\text { Matching between Family Needs and Possibilities of the } \\
\text { Programme }\end{array}$ & 2 & 1 & PRA \\
\hline & M 5.5 & Ways of Evaluating the Interventions & 2 & 1 & $\begin{array}{l}\text { EXA } \\
\text { PRA }\end{array}$ \\
\hline & \multicolumn{2}{|l|}{ Sum } & 10 & & \\
\hline \multirow{2}{*}{ 炡 } & M 6 & Personal Competences & 5 & 2 & WRF \\
\hline & \multicolumn{2}{|l|}{ Sum } & 5 & & \\
\hline
\end{tabular}




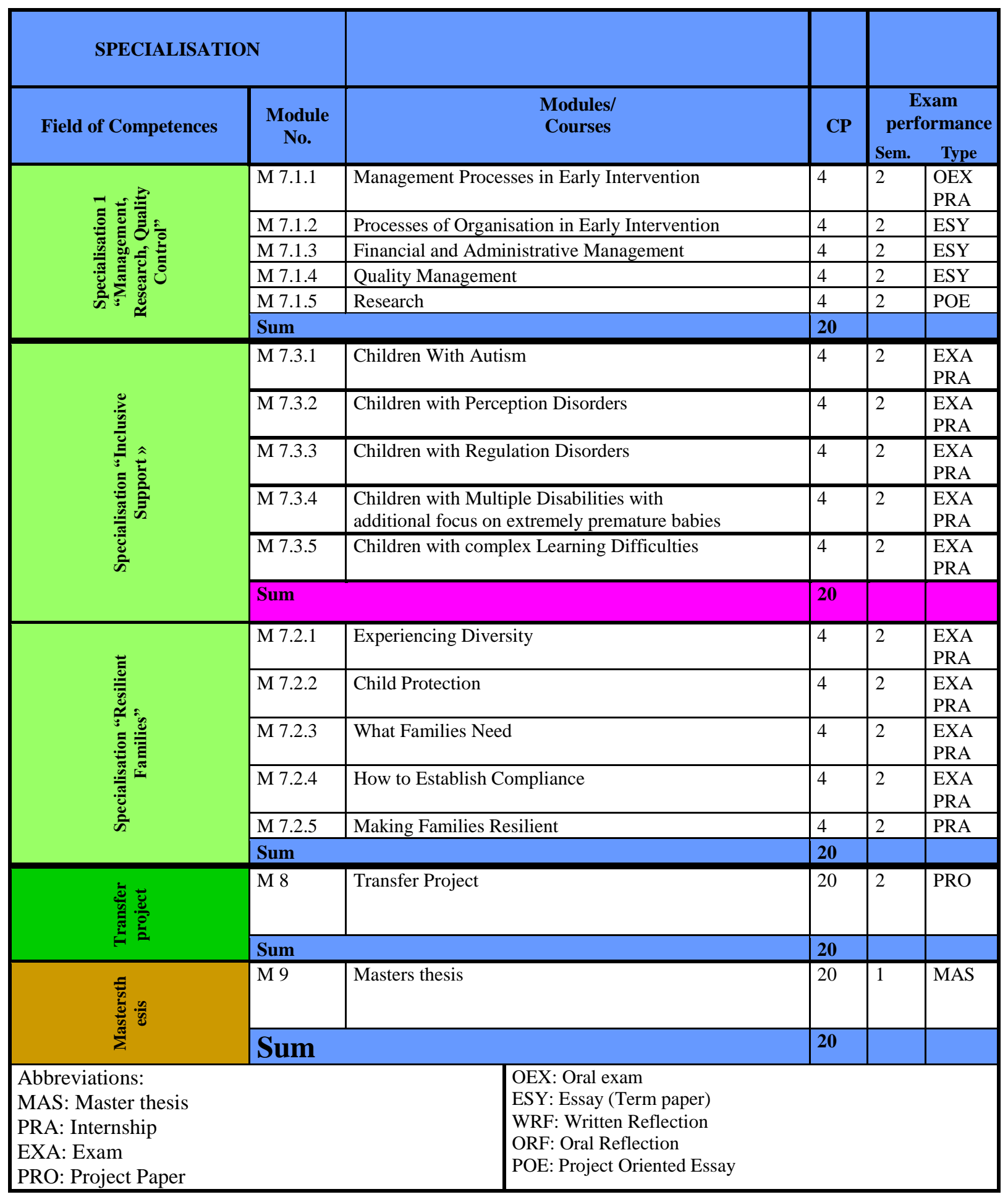

\section{PRECIOUS Resource POOL}

A further focus of activities addressed the creation and accessibility of training resources, primarily using the internet. Following the structure of the European curriculum, partners and training institutions have the possibility to upload relevant training literature to be used by professionals or training institutions. This is of special interest as for the first time, specific training materials which are normally labelled "grey literature" and mostly used during training programmes, is available for the public, in different languages. 
Graph 1. Screenshot of the PRECIOUS resource pool

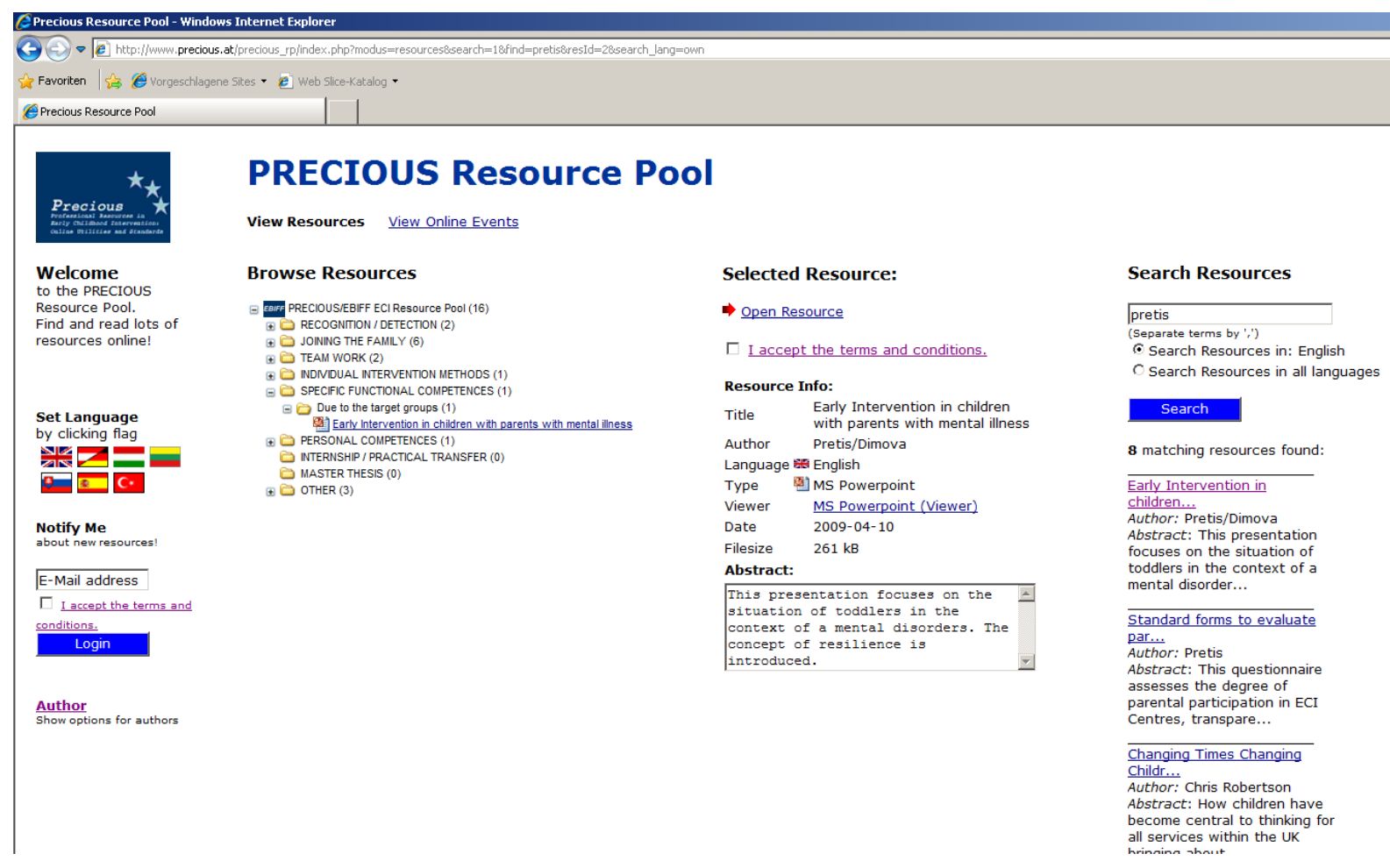

More than 130 training resources in 8 languages have been uploaded and can be used by interested learners. Therefore, the PRECIOUS resource pool represents a complementary structure to the international professional library of the International Society on Early Childhood Intervention (http://depts.washington.edu/isei/ptrl/PTRL_Purpose.php).

\section{Precious Learning Platform}

A third process focused on the creation of a training and communication platform on the internet. Through a range of pilot runs, the possibilities as well as challenges and limitations of training and learning via the online platform were assessed. In small groups with clear didactical approaches, pilot seminars could be organised. However the training platform also offered the possibility to download relevant course material e.g. relating to early childhood intervention or new vulnerable groups. Open distance learning tools - in future - can be assessed as powerful instruments to increase the efficiency of professional training, especially regarding issues of knowledge transfer.

\section{The results of the international cooperation}

As a result of the PRECIOUS group activities towards implementation a masters program will start in three German universities

a. as a full-time masters course at the Medical School Hamburg (www.medicalschoolhamburg.de)

b. at the University of Applied Science at Gera (www.gesundheitshochschule.de)

c. at the University of Applied Science at Nordhausen (www.fh-nordhausen.de)

Having finished the accreditation processes in autumn 2010 these two universities will offer masters degrees starting from 2011. These first Masters degrees will provide an input towards the professional system in Germany as for the first time, after finishing their degree, students 
will be "early interventionists". It can be hypothesised that Masters graduates in early childhood intervention will mainly work on highly specific management issues for leading positions in centres in the form of mentors for the centres or other colleagues in the field.

Furthermore, the following initiatives have started within the PRECIOUS project

d. development of a continuous education initiative in Hungary

e. Initiatives in Turkey and in Slovakia

Alongside these accreditation processes, initiatives were started in Turkey, Lithuania, Slovakia and Hungary. In Turkey education towards a first Masters degree in early childhood intervention was submitted to the higher education council. In Hungary, due to activities within the project conference in 2009, the Hungarian project partner was asked to submit a specific training programme of early childhood interventionists for accreditation. This training is currently accredited in cooperation with a university in Budapest. In Slovakia early childhood intervention in terms of a sub-specialisation was introduced into the curriculum of therapeutic educators, and specific training offers were created for health professionals. In Lithuania the previous centre-based early childhood intervention was under discussion and within the project time, mobile services were implemented, strengthening the idea of fostering families in their natural contexts.

\section{Publications and public awareness}

In order to stimulate structural changes and impact on national standards, different conferences (in Hungary, Budapest in April 2008, Turkey, Eskisehir in September 2009, in Germany, Gera, September 2010) PRECIOUS also initiated a practical catalogue about standards; defining procedures of strengths and challenges of early childhood intervention systems in Europe. Real impacts can also be observed regarding the increased participation of parents e.g in the quality assessment of ECI centres or regarding professional training.

\section{Future challenges}

The projects www.ebiff.org, www.precious.at and www.stong-kids.eu represent a strong impulse regarding the need and concrete organisation of training in the field of early childhood intervention - addressing the following issues and proposing solutions:

Table 2. Challenges within the training system in Early Childhood Intervention

\begin{tabular}{|c|c|}
\hline Training related aspect & Proposed solution within PRECIOUS \\
\hline $\begin{array}{l}\text { National diversity in training and access to the } \\
\text { professional field }\end{array}$ & $\begin{array}{l}\text { Use of the Ebiff-assessment instrument to assess } \\
\text { the match between personal or institutional } \\
\text { portfolio with the European curriculum } \\
\text { framework }\end{array}$ \\
\hline Lack of specific training courses & $\begin{array}{l}\text { For the German, Turkish and Hungarian context } \\
\text { courses were designed. For Spain and Austria } \\
\text { specific trainings are or will be available. }\end{array}$ \\
\hline Lack of professional resources & Availability of an online resource pool \\
\hline Mainly face-to-face organised trainings & $\begin{array}{l}\text { Use of ODL structures for knowledge-related } \\
\text { training components. }\end{array}$ \\
\hline
\end{tabular}

Even though in some EU27 member countries structured efforts towards comparable professional training can be observed, issues still remain:

- diversity of languages 
- affordability for professionals (directly connected with the "pricing" of training)

- or concrete organisation of multilingual courses (especially regarding the need of new member states in Central and East Europe.

It must not be forgotten that one major effect of our European cooperation is to create networks and better understanding. 


\section{References}

Applequist, K.L., McLellan, M., McGrath, E.R. (2010). The Apprenticeship Model. Assessing Competencies of Early Intervention Practitioners. Infants and Young Children, 23(1), 23-33

Bailey, D.B. Palsha S.A, Simeonsson R.J (1991). Professional Skills, Concerns, and Perceived Importance of Work with Families in Early Intervention. Exceptional Children, 58(2) 156-65.

Carpenter, B., Herbert, E. (1994). The peripheral parent: research issues and reflection on the role of the fathers in early intervention. PMLD Link (Summer), 19.

Carpenter, B. (1997). Early Intervention and Identification of Young Children at Risk. Working as a team with and through the family. Children and Society, 11.

European Agency (2005). Early Childhood Intervention: Analysis of Situations in Europe Key Aspects and Recommendations. Available on the http://www.europeanagency.org/publications/ereports/early-childhood-intervention/early-childhoodintervention-analysis-of-situations-in-europe-key-aspects-and-recommendations website (retrieved 22.7.2010).

Eurlyaid (Eds.) (1997). Meeting of the working party Eurlyaid Cannaro, 9-12.10.1997. (unpublished working paper).

Granlund, M., Björck-Åkesson, E. (1996). Inservice training of pre-school consultants in family-oriented intervention: Training process and outcome. British Journal of Developmental Disabilities, 42, 1-23.

Maude, S.P., Catlett, C., Moore, S., Sánchez, S.Y., Thorp, E.K., Corso, R. (2010). Infusing Diversity Constructions in Preservice Teacher Preparation. Infants and Young Children, 23(2), 103-121.

McMullen, M. B., Alat, K. (2002). Education matters in the nurturing of the beliefs of early childhood professionals. Early Childhood Research and Practice, 4(2). Available on the http://www.ecrp.uiuc.edu/v4n2/mcmullen.html website (retrieved 22.7.2010).

Peterander, F. (1996). Helios II final report. Early Intervention. Information, Orientation and Guidance of Families. Thematic Group 1. München: Universität München.

Pretis, M. (1998). Evaluation interdisziplinärer Frühförderung und Familienbegleitung bei Kindern mit Down Syndrom. Bedingungs- und Wirkfaktoren, kovariierende Variablen. Frühförderung interdisziplinär, 17, 49-64.

Pretis, M. (2006). Professional Training in Early Intervention. A European Perspective. JPPID, 3(1), 22-48.

Speck, O. (1996). Frühförderung entwicklungsauffälliger Kinder unter ökologischintegrativem Aspekt. In: F. Peterander; O. Speck (Eds.), Frühförderung in Europa, 1423. München: Reinhardt.

www.ebiff.org (retrieved 22.7.2010).

http://depts.washington.edu/isei/ptrl/PTRL_Purpose.php (retrieved 22.7.2010).

www.strong-kids.eu (retrieved 22.7.2010).

www.precious.at (retrieved 22.7.2010).

www.medicalschool-hamburg.de (retrieved 22.7.2010)

www.european-agency.org/agency-projects/early-childhood-intervention (retrieved

22.7.2010)

www.gesundheitshochschule.de (retrieved 3.8.2010)

www.fh-nordhausen.de (retrieved 3.8.2010) 